\title{
A (auto)representação do negro no conto brasileiro contemporâneo
}

\author{
Luciene Azevedo* \\ Samara Lima**
}

\section{Questões sobre a representação}

bell hooks (2019) em seu ensaio O olhar opositor: mulheres negras espectadoras reflete sobre como os corpos das mulheres negras estão inseridos nas telas do cinema estadunidense. Segundo hooks, mesmo quando as mulheres negras estão presentes, muitas vezes, são representadas de forma subalternizada. Ao escrever um ensaio sobre a sua experiência de desconforto ao assistir a "Imitação da vida" (1934) com sua irmã e acompanhar a trajetória da personagem Peola, comenta:

Sempre me lembrarei dessa imagem. Eu me lembro de como chorei por ela, por nossas existências desejantes irrealizadas. Ela era trágica porque não havia lugar para ela no cinema, nenhum filme de amor. Ela também era uma imagem ausente. Era melhor, então, que estivéssemos ausentes, porque, quando estávamos presentes, era humilhante, estranho, triste (Hooks, 2019, p. 225).

Como espectadora crítica, hooks traz um termo muito interessante, cunhado por Julie Burchill, para pensar a caracterização que Hollywood faz das mulheres negras em Girls on Film (1986 apud hooks, 2019, p. 221): presença ausente. As imagens são estereotipadas, por isso, a denominação "ausente". Elas não visam apresentar a complexidade da subjetividade da mulher negra. São representações que perpetuam imagens agressivas em uma sociedade racista e sexista e que reforçam o imaginário social da mulher negra como um ser para a servidão, mantendo o lugar de opressão em que vivem na sociedade. Pois bem. É justamente a partir dessa visão que gostaríamos de abordar as representações convencionais dos sujeitos negros na literatura brasileira. Ainda que o conceito para bell hooks esteja

\footnotetext{
Doutora em Literatura Comparada e professora do Departamento de Fundamentos para o Estudo das Letras e do Programa de Pós-graduação em Literatura e Cultura da Universidade Federal da Bahia (UFBA), Salvador, BA, Brasil. E-mail: aaluciene@gmail.com.

** Graduanda em Língua Estrangeira na Universidade Federal da Bahia (UFBA), Salvador, BA, Brasil. E-mail: samaracdlima@gmail.com.
} 
vinculado às representações televisivas e cinematográficas, não deixa de ser notável a "presença ausente" desses grupos que, quando aparecem, é de forma secundarizada e estereotipada nas narrativas. A fim de entender tais representações negativas foi necessário um pequeno passeio pela crítica a respeito do personagem negro na narrativa literária brasileira.

Neste caso, destacamos a importância de Domício Proença Filho que, em seu artigo A trajetória do negro na literatura brasileira (2004), discute a forma como esses sujeitos foram estereotipados por meio de análise de personagens de obras clássicas, como a escrava Isaura, do livro homônimo, lançado em 1872. No caso de Isaura, Proença Filho interpreta sua situação como "escravo nobre" (ProençA FILHo, 2004, p. 162) que vence por causa do seu branqueamento, embora à custa de muita humilhação. Quando Sinhá Rita adverte Isaura de que ela não tinha do que reclamar, uma vez que deveria ser motivo de inveja de muita gente livre devido à educação que recebera e ao fato de ter pele branca, Isaura responde:

Mas senhora, apesar de tudo isso que sou eu mais do que uma simples escrava? Essa educação, que me deram, e essa beleza, que tanto me gabam, de que me servem?... São trastes de luxo colocados na senzala do africano. A senzala nem por isso deixa de ser o que é: uma senzala (ProençA Filho, 2004, p. 162).

Segundo o teórico, o "escravo nobre" é aquele que mesmo sabendo a condição em que se encontra, preso ao trabalho forçado, aceita a submissão, a posição que lhe é imposta, sem julgamentos e questionamentos.

Conceição Evaristo, em seu texto Da representação à auto-representação da mulher negra na literatura brasileira (2005), ao analisar obras como O cortiço (189o), de Aluísio de Azevedo, tece uma breve discussão sobre a representação literária da mulher negra. Segundo a autora, essas personagens ainda surgem ligadas às imagens de seu passado escravo, que são encontradas desde o período da literatura colonial, a saber: "corpo-procriação" e "corpo-objeto de prazer do macho senhor" (Evaristo, 2005, p. 52). Conceição Evaristo ressalta a ausência de representação positiva da mulher negra como matriz de uma família. $O$ fato é que quase sempre essas personagens aparecem como "infecundas, perigosas e animalizadas" (Evaristo, 2005, p. 53). Basta lembrar o destino da personagem Bertoleza, que morre "focinhando" (EvARISTO, 2005, p. 53).

Outra avaliação, consoante o pensamento de Conceição Evaristo, foi proferida por Eduardo de Assis Duarte em seu texto O negro na literatura brasileira (2013). O teórico analisa como a negritude está inscrita em nossa literatura, discutindo o modo como a presença do negro no arquivo literário, construído pelos manuais canônicos, mostra-se "rarefeita e opaca" (DUARTE, 2014, p. 146). Refletindo sobre a figuração feminina negra na obra Vítimas algozes: quadros da escravidão (1869), de Joaquim Manuel Macedo, Duarte discute como o protagonismo feminino é 
marcado por um projeto de desumanização. Esse projeto está presente em construções textuais que ressaltam imagens sociais determinadas a priori. Por exemplo, o imaginário social da mulher negra como "mulata assanhada" (DuARTE, 2014, p. 146), disponível para o sexo sem compromisso e responsável pela destruição de casamentos e famílias. Para ele, essas textualidades sequestram o negro enquanto individualidade pensante, enquanto voz narrativa, negando a própria humanidade "à maioria dos brasileiros ao retratá-los sob a moldura estreita ditada pelos estereótipos e pelos metarrelatos da cordialidade e da democracia racial” (Assis DuARTE, 2013, p. 148).

É interessante notar que a "presença ausente" dos sujeitos negros, perpetuada na literatura brasileira por meio de personagens caricatos difere das representações do negro na produção ficcional machadiana. Através da fundamentação teórica de textos como Estratégias de Caramujo (2007), de Eduardo de Assis Duarte, que objetiva situar a obra do escritor na discussão sobre literatura afrodescendente ao analisar contos, como "O caso da vara" (1899) e "Pai contra Mãe" (1906), é possível perceber que Machado de Assis não optou pelo confronto abertamente engajado e comprometido com a causa do negro na sociedade oitocentista, mas pela utilização de recursos literários como a ironia, o humor e a mudança de foco narrativo para inscrever seu posicionamento enquanto sujeito negro numa sociedade racista.

À primeira vista, seus contos parecem tratar das peripécias dos personagens elitizados e caracterizar o personagem negro como pano de fundo da cena. Entretanto, pouco a pouco, os personagens que antes pareciam secundários, ganham protagonismo e se revelam como parte fundamental para o desenrolar do enredo. Nomeando essas estratégias como "poética da dissimulação" (2009, p. 282), Duarte afirma que o jogo entre o dito e o não dito é parte inerente à construção do sentido da produção machadiana. O primeiro movimento para discutir a produção do Bruxo do Cosme Velho foi pensar o contexto histórico em que o autor estava inserido. A sociedade do século XIX era escravagista e marcada pela crença no embranquecimento racial, na qual a cultura branca, ocidental, europeia e discursos de desvalorização dos negros e mestiços se constituíam como referência de civilização. A valorização da etnicidade por parte da população negra foi, muitas vezes, reprimida como forma de sobrevivência.

Porém, a contemporaneidade vem sendo marcada por um contexto de efervescência cultural e política em que movimentos sociais buscam repensar diversas estruturas da sociedade e discursos cristalizados no imaginário coletivo. O campo literário brasileiro, que também se constitui enquanto esfera de produção de discurso, não fica imune a tais tensões. No contexto da literatura brasileira, é notável como o trabalho de temas que envolvem a dimensão do negro na obra de Machado de Assis no século XIX ecoe em produções que, atualmente, reivindicam maior representatividade nas esferas políticas e sociais, pondo em xeque problemas relacionados ao racismo e à condição do negro no século XXI. 
Cada vez mais os sujeitos negros e seus descendentes, que na historiografia literária foram apresentados sob tutela, subalternizados e, em tantas outras vezes, simplesmente excluídos das representações, estão reivindicando a autorrepresentação. Os autores não mais necessitam utilizar os artifícios de Machado. Hoje, os autores negros reivindicam a possibilidade de marcarem um lugar de presença, de manifestarem abertamente em seus escritos o comprometimento com a etnia e questionarem os estereótipos cristalizados no imaginário social.

No texto "Autorrepresentação e intervenção cultural em textualidades afrobrasileiras" (2010), Florentina Souza lembra como os intelectuais afrodescendentes buscaram, através de ações e intervenções culturais, participar de debates políticos de seu tempo, ainda que a sociedade brasileira criasse, sistematicamente, barreiras à legitimação de suas produções e, claro, às suas lutas. Os objetivos dos intelectuais afro-brasileiros apontados pela autora entram em compasso com as poéticas dos autores negros que pretendemos analisar:

Estes intelectuais negros/as criam estratégias para questionar as estruturas de pensamento, gosto e valor instituídas pelo sistema simbólico, bem como inserir seus capitais intelectuais e simbólicos no campo das produções intelectuais do país, intervindo na vida político-cultural brasileira (SouzA, 2010, p.184).

O que chamamos de autorrepresentação, então, diz respeito ao posicionamento afirmativo cada vez mais recorrente na literatura brasileira recente por parte dos escritores afrodescendentes, como Cidinha da Silva, Geovani Martins e Cristiane Sobral. Tendo como base o livro de Stuart Hall, Cultura e Representação (2016), pensamos a (auto)representação a partir da noção construtivista, em que os significados só acontecem em função de convenções sociais ligadas à linguagem, que funcionam como sistema de codificação do mundo, compartilhados socialmente e que são produzidos por meio de práticas sociais. Esses autores, portanto, buscam a possibilidade de se inserirem no campo de saber e no circuito da representação enquanto produtores de significados.

Diante de tantos autores que reivindicam a possibilidade de falar por si, a reação ao termo "autorrepresentação" é grande. Florentina Souza, no texto supracitado, comenta como Lima Barreto, que optou por um confronto abertamente engajado de valorização de sua etnia em seu projeto literário, "é sobejamente caracterizado pela crítica como 'ressentido" (SouzA, 2010, p. 155). Em momento anterior, esse epíteto também foi proferido pelo importante crítico literário norteamericano Harold Bloom, em seu livro O cânone Ocidental, ao batizar de "Escola do Ressentimento" (BLOOM, 2010) as produções dos autores pertencentes às minorias étnicas e sociais. Nossa preocupação, então, é valorizar essas narrativas e rejeitar a ideia de ressentimento e vitimização. Para além de pensar a biografia dos autores e suas produções como "contranarrativas", isto é, como respostas aos discursos acusatórios direcionados à sua raça, tentamos analisar as estratégias pre- 
sentes em suas textualidades para apontar que as narrativas buscam a afirmação da identidade racial e muito mais.

Ana Maria Gonçalves, em seu texto "Literatura dos povos que faltam" (2019), reivindica essas outras vozes (e cores) na literatura, a fim de revelar uma literatura brasileira marcada pelo múltiplo, com perspectivas sociais que antes não apareciam no discurso literário nacional. No texto, Gonçalves traz uma discussão muito importante oferecida por Deleuze e Guattari no livro Kafka: por uma literatura menor (2017), para entendermos a literatura desses "povos que faltam". Os filósofos propõem três aspectos característicos para entendermos essa literatura menor. Cabe ressaltar que o "menor" não está ligado a juízo de valor, mas sim a produções construídas por grupos historicamente subalternizados e à margem das instâncias de poder, por isso a denominação "povos que faltam".

A primeira proposição diz respeito ao fato de que os escritores menores ao construírem suas produções a partir de uma língua maior, promovem uma "desterritorialização" (Deleuze, Guattari 2017, p. 35). Esses autores, aqui, afrodescendentes, tiram a língua portuguesa (língua maior) de seu território a partir do momento em que ressignificam e descontroem determinadas representações criadas na e pela linguagem. A segunda característica apontada pelos filósofos é a "natureza política de seu enunciado" (Deleuze, Guattari, 2017, p. 36), em que todo individual está ligado ao imediato político. $\mathrm{O}$ fato é que as questões levantadas pelos autores em suas textualidades, como as questões raciais no Brasil, muita vezes, fortalecem discussões politicas e históricas mais amplas. Assim, chegamos ao terceiro aspecto, em que todo enunciado "adquire um valor coletivo" (Deleuze, Guattari, 2017, p. 37). A autorrepresentação que os autores afrodescendentes reivindicam em suas produções ficcionais não é narcisista, o debate não se encerra nele mesmo. As narrativas que tematizam as representações do negro, quando escritas por autores negros, transcendem a compreensão de que é um problema próprio aos autores, pois diz respeito a uma esfera coletiva. Esses escritores, segundo Deleuze, escrevem "por esse povo que falta" (2011 apud GonçALVES, 2019, p. 119), escrevem pelas vozes historicamente silenciadas pelos instrumentos coercitivos de dominação colonial.

Uma vez que a manifestação literária tem a capacidade de (re)inventar positivamente essas tantas identidades, os autores que passaram por um processo de autoafirmação de sua identidade estão buscando desenvolver narrativas com um olhar de quem é de dentro. Visam criar representações humanizadas que abarquem a complexidade de suas subjetividades e experiências enquanto sujeitos negros que representam $54,10 \%$ da população, segundo os dados do Instituto Brasileiro de Geografia e Estatística (IBGE), em 2015. ${ }^{1}$

\footnotetext{
Ver os dados da população brasileira divulgado em 2015 pelo IBGE: https://economia.uol.com. $\mathrm{br} /$ noticias/redacao/2015/12/o4/negros-representam-54-da-populacao-do-pais-mas-sao-so-17dos-mais-ricos.htm
} 
Em Exposições e críticos de arte afro-brasileira: um conceito em disputa (2018), Helio Menezes Neto analisa a problemática conceitual de "arte afro-brasileira". Para ele, a terminologia é provisória e depende da perspectiva que cada curador adotará ao realizar a exposição. Podendo oscilar entre: forma, as características materiais do fazer artístico; tema, os "motivos da cultura e sociabilidade afro-brasileiras"; e, por fim, autoria negra enquanto critério de definição. A discussão que o autor empreende sobre a inserção de artistas negros na definição de "arte afro-brasileira" foi crucial para esta reflexão.

Circunscrever a inventividade de artistas negros, de modo a buscar uma linha que os unifique, com um afinamento temático ou iconográfico na feitura de seus trabalhos, é como querer que massas e maçãs, pela similitude de seus nomes, tenham o mesmo gosto ou atendam aos mesmos propósitos. Como bem disse Franz Fanon (1925-1961): "Não há um preto, há pretos" (MenEzes Neto, 2018).

O comentário do teórico é muito pertinente, pois foi a partir desse pensamento que igualmente objetivamos refletir sobre o pertencimento étnico de cada escritor em suas produções ficcionais. Ou seja, o esforço para delimitar a autorrepresentação é importante, mas é necessário perceber que cada autor irá utilizar diferentes estratégias literárias para inscrever sua negritude na narrativa e se posicionar frente às mazelas enfrentadas pelo negro no século XXI. Nesse sentido, visamos confrontar a ideia de (auto)representação, para, assim, articular, através da análise de contos como "Metal-Metal" (2019), de Cidinha da Silva, "Elevador a serviço" (2016), de Cristiane Sobral, e "Espiral" (2018), de Geovani Martins, como esses autores abordam, na escrita, problemáticas relativas às questões raciais no Brasil.

\section{Novas narrativas. As estratégias da representação do negro no conto brasileiro contemporâneo}

Em Eu queria saber o que os homens brancos pensavam de seu privilégio. Então perguntei (2019), Claudia Rankine, a partir da sua condição de mulher negra, tece uma discussão sobre a identidade racial branca e sua associação com a universalidade. Um dos dilemas da autorrepresentação dos sujeitos negros com que nos deparamos é o questionamento sobre se é possível pensar a (auto)representação da negritude sem levar em consideração a visão estereotipada que o sujeito branco confere a eles. Ou seja, se dá para pensar a negritude sem pensar a branquitude. Para Rankine, a resposta é não: "Eles não poderiam saber o que é ser como eu, embora quem eu sou seja em parte uma resposta a quem eles são"(RANKINE, 2019, p. 81).

Segundo a teórica, é importante reconhecer que há uma dialética entre as duas identidades, em que a branquitude existe uma vez que é construída por meio do racismo e a negritude existe pelo fato de ser considerado como alteridade, ocupando sempre o lugar do "outro". Sem lamento, fórmula pronta ou evocação de autoridade, o leitor se depara, no decorrer do ensaio, com as tentativas de diálogo que a teórica visa empreender com os homens brancos. A autora busca entender 
se eles compreendem a liquidez de seus movimentos no mundo. Por exemplo, circular em determinados locais sem serem barrados ou questionados sobre sua presença. O que é interessante nesse contexto é que em cada diálogo Claudia Rankine precisa negociar as representações que estão em jogo. Ela precisa negociar a forma como a sociedade a enxerga em oposição à sua vontade de ser o que quiser. Um exemplo é a situação em que estava na fila de primeira classe para um voo e um homem branco passou na sua frente:

Ele estava com outro homem branco. "Com licença”, eu disse, "estou na fila”. Ele deu um passo para trás, mas não antes de dizer ao seu companheiro, "hoje em dia você nunca sabe quem eles estão aceitando na primeira classe" (RANKINE, 2018, p. 82).

Mesmo sendo uma conceituada professora da Universidade de Yale, em que sua condição social permite que ela se locomova e viaje para outros países, no processo de socialização com os sujeitos brancos, eles questionam o fato de ela ocupar esses espaços. Segundo a autora, é uma constante sensação de "estar-nãoestar" (RANkine, 2018). A cor de sua pele, ao mesmo tempo em que a destaca (a faz estar), a torna alvo de atitudes racistas e a invisibiliza. Não à toa o homem branco sente-se legitimado para passar à sua frente. No texto abordado anteriormente, Florentina Souza (2010), também traz um conceito interessante para a negociação entre a identidade do sujeito negro e a representação estereotipada que a imaginação branca impõe à sua raça: a ideia de "dupla consciência" de que fala Du Bois (1999 apud SouzA, 2010):

[A] sensação de estar sempre a se olhar com os olhos dos outros, de medir sua própria alma pela medida de um mundo que continua a mirá-lo com divertido desprezo e piedade. E sempre a sentir sua duplicidade [...]: duas almas, dois pensamentos dois esforços irreconciliados: duas ideias que se combatem em um corpo escuro (Du BoIs, 1999, p. 54 apud SouzA, 2010, p. 186).

Esse embate entre as duas representações, que implica em posturas distintas em relação à ocupação dos espaços pelos sujeitos negros, está presente também na representação literária. "Espiral" (2018), conto de Geovani Martins, é exemplar em demonstrar a confrontação agressiva das representações negativas sobre sujeitos negros. O conto, publicado no livro $O$ sol na Cabeça (2018), trata do comportamento, em um primeiro momento questionável, de um narrador sem nome e cor, que persegue outros personagens. Se a falta de características do protagonista parece proposital por não querer firmar uma identidade específica, logo a narrativa vai criando uma dualidade explícita:

Começou muito cedo. Eu não entendia. Quando passei a voltar sozinho da escola, percebi esses movimentos. Primeiro com os moleques do colégio 
particular que ficava na esquina da rua da minha escola, eles tremiam quando meu bonde passava (MARTINS, 2018, p. 17).

O leitor infere pelas informações do primeiro parágrafo que o narrador é olhado pelos "moleques do colégio particular" como o "outro". Ainda que o narrador não seja caracterizado como negro, a sociedade brasileira é pródiga em exemplos que confirmam como a alteridade provoca medo. É o que acontece em relação ao racismo. Emicida, um cantor de rap, negro, por exemplo, expôs no Portal Geledés que "a pior coisa é você perguntar as horas, e a pessoa esconder a bolsa" (EMICIDA, 2015). ${ }^{2}$

O narrador não sabe direito por que provoca temor nos garotos da escola particular. Aos poucos, o que antes chegava a ser "engraçado" (MARTins, 2018, p. 17), porque ele e seus amigos da própria escola não provocavam medo em ninguém, transforma-se na consciência de sua condição. Foi diante de experiências como essas que o narrador começa a perseguir pessoas nas ruas, como "estudo das relações humanas" (MARTINs, 2018, p. 19), mas também, para assumir o controle de suas reações:

Nunca esquecerei da minha primeira perseguição. Tudo começou do jeito que eu mais detestava: quando eu, de tão distraído, me assustava com o susto das pessoas e, quando via, era eu o motivo, a ameaça. Prendi a respiração, o choro, me segurei, mais de uma vez, para não xingar a velha que visivelmente se incomodava de dividir comigo, e só comigo, o ponto de ônibus. No entanto, dessa vez, ao invés de sair de perto, como sempre fazia, me aproximei (MARTINS, 2018, p. 18).

Assim como no episódio narrado por Rankine, a idosa não acredita que o narrador tenha o direito de ocupar o lugar a seu lado, ainda que o ponto de ônibus seja um espaço público. Ele é invisibilizado ao mesmo tempo em que sua cor é a condição fundamental de sua existência no espaço público social. O narrador opta por confrontar e assumir as representações estigmatizadas conferidas a ele, pois resolve perseguir a idosa que "começou a olhar em volta, buscando ajuda" (MARTINS, 2018, p. 18), sempre protegendo sua bolsa.

Esse episódio pode tornar mais clara a ideia de "dupla consciência" de Du Bois, pois duas representações divergentes formam um conflito na consciência do narrador, uma vez que a narrativa evidencia um confronto entre a imagem estereotipada imposta a ele pela senhora e a forma humanizada como descreve o narrador, quem ele realmente é: um jovem que tem "vó, mãe, família, amigos, essas coisas todas que fazem nossa liberdade valer muito mais do que qualquer bolsa, nacional ou importada" (MARTins, 2018, p. 19).

\footnotetext{
A esse respeito, recomendamos a entrevista de Emicida ao Portal Geledés. Disponível em: https://www.geledes.org.br/emicida-pior-coisa-e-voce-perguntar-as-horas-e-a-pessoaesconder-a-bolsa/.
} 
Martins afirma que gosta de omitir a cor da pele dos personagens, mas que ainda assim costuma receber comentários sobre as situações narradas em que os protagonistas são imaginados como negros pelos leitores. Outro aspecto que chama atenção na narrativa é o fato de o protagonista não ter nome, o que pode representar, através do personagem, todos os jovens que crescem sendo alvo de medo, fruto do racismo estrutural existente na sociedade. Mas também, o fato de a violência racial ser abordada a partir da perspectiva de um adolescente. Essa característica provoca um efeito profundo no leitor, cria um incômodo, pois somos levados a criar uma empatia com o personagem violentado e somos forçados a questionar a atitude (racista) da senhora.

Assim, é possível enxergar na narrativa de Martins um outro lado da vida dos sujeitos subalternizados, que supera a "presença ausente" recorrente no discurso literário. O personagem de Geovani Martins não é opaco e aborda os dramas internos enfrentados por muitos jovens que, diariamente, necessitam negociar as representações e "recusar os estereótipos da negritude criados [...], ainda que [...] interaja[am] com esses estereótipos" (RANKINE, 2019, p. 85). Cada escritor afrodescendente utilizará diferentes recursos para inscrever o seu posicionamento frente às problemáticas do negro na sociedade brasileira. A opção de Martins por não marcar seu personagem racialmente pode ser justificada por um comentário de outro escritor:

\footnotetext{
Nos meus livros, nunca digo que um personagem é negro. Nunca digo, o leitor vai ter que descobrir. Vou dar indicações. [...] É um desafio, é difícil. Antigamente, em lingüística, isso era chamado de "elemento marcado". O elemento marcado era aquele que você "tinha que dizer". Quando você não diz alguma coisa, presume-se outra. Então, a literatura presume-se uma coisa de brancos. Escritores brancos e leitores brancos. Quando aparece um elemento negro, ele tem que ser marcado (Mussa, 2011).
}

A representação desse "estar-não-estar", da dupla consciência (Du Bois), do confronto da consciência da negritude com o estereótipo da branquitude também pode ser observada no conto "Elevador a serviço" (2016). Assim como no conto de Geovani Martins, Cristiane Sobral também opta por abordar a representação da negritude em confronto com a imaginação branca. O conto, publicado no livro $O$ tapete voador (2016), trata uma cena de racismo durante uma conversa no elevador. A narradora, que se chama Malena, é cantora, aparentemente reconhecida, e estava a caminho do estúdio para discutir a "possibilidade de montar um show com repertório de músicas da Jovelina [...] e outras compositoras negras" (SOBRAL, 2016, p.27):

Saiu de casa para mais um dia de ensaios. Com passos tranquilos, resolveu pegar o elevador de serviço, já que o outro parecia ter travado na recepção. Entrou no elevador do prédio de luxo no $12^{\circ}$ andar assoviando uma música de Jovelina Pérola Negra (Sobral, 2016, p. 27). 
Cabe ressaltar que, nesse conto de Sobral, não há marcação étnica na personagem afrodescendente, assim como no conto de Martins. Mas no decorrer da narrativa, a narradora confere várias simbologias que permitem que o leitor infira a ascendência da personagem, como quando a narradora relata que "desde a infância, [...] sua mãe cantava e alimentava os filhos com palavras de exaltação à cultura negra" (SoBRAL, 2016, p. 27). Ou quando a senhora branca, numa falha tentativa de puxar conversa no elevador, comenta sobre o cabelo da narradora afirmando que acha "o máximo quando as mulatas assumem a sua raça" (Sobral, 2016, p. 28). No elevador, entra "uma senhora branca de meia-idade" (SoBrAL, 2016, p. 27) que, puxando conversa, pergunta à narradora: "Será que você não poderia me indicar alguém assim como você para trabalhar em minha casa? Preciso tanto de uma empregada" (SOBRAL, 2016, p. 28).

A senhora supõe que Malena, por ser negra e circular em um prédio de luxo, é empregada. Esse conflito está presente já no próprio título do conto "Elevador a serviço". O título dá a entender que a narradora existe "a serviço dos brancos", no caso da história, "a serviço da senhora", pois a senhora já adentra o elevador com uma representação negativa da negritude, enquanto Malena, desde o início da narrativa, já é caracterizada integralmente: ela é uma cantora, independente, que valoriza as suas raízes. Após o ocorrido, a narradora questiona o comportamento racista da senhora e resolve "dar uma resposta à altura" (SOBRAL, 2016, p. 29):

Sabe, eu também estou procurando alguém que possa me atender profissionalmente, assessorar quero dizer. Será que a senhora não teria alguma indicação? Uma filha, uma sobrinha ou afilhada? (SoBrAL, 2016, p. 29).

No final do conto, a personagem decide combater o racismo, defender suas raízes e fazer um show que invocasse a memória de suas ancestrais. Uma das estratégias utilizadas pela narradora é mostrar, desde o começo, a visão politizada de Malena ao rememorar aspectos da infância com a sua família. Assim, a estratégia foca em uma construção de identidade negra que inverte as "imagens ausentes" as quais, durante muito tempo, perduraram na representação literária, já que subverte as representações da negritude relacionada à subserviência e à vitimização e as atuações dos personagens negros relegados a papéis secundários. A protagonista, ao colocar a descendência da senhora branca como também passível de trabalhar para ela, interroga o olhar do outro e constrói um espaço onde se articula e atua politicamente. No conto de Sobral, a autorrepresentação está ligada à própria ideia do fazer literário que a autora reivindica. Ao ser perguntada em uma entrevista sobre qual elemento da literatura a autora vincula à sua experiência enquanto mulher negra, Cristiane Sobral responde:

A busca de construções humanizadas [...]. Os personagens são vencedores, em que pesem as derrotas cotidianas e os fracassos humanos. As personagens não representam, elas são. Há uma consciência política, ideoló- 
gica e estética e uma referência às tradições, à ancestralidade, à contemporaneidade e um protagonismo negro na contação de histórias na prosa e na poesia (Sobral, 2017).

O conto de Sobral nos faz pensar no panorama brasileiro, pautado em um racismo estrutural que rege as formas de socialização. Tendo em vista que as representações influenciam a nossa forma de conceber o mundo e, consequentemente, de nos entendermos enquanto indivíduos, narrativas como essas podem atuar sobre o modo como a sociedade lida com o processo de invisibilidade e exclusão em relação aos sujeitos negros.

bell hooks em seu ensaio Amando a negritude como resistência política (2019) critica o fato de muitas representações ainda se basearem na relação dialética entre a identidade "negra e a desconstrução da categoria "branquitude" (hooks, 2019, p. 50). A contrapelo da visão de Claudia Rankine, hooks acredita que é possível um investimento crítico que supere a representação da negritude como o lado inseparável da branquitude. A posição de hooks pode ser tomada como uma estratégia do conto "Metal-Metal" (2019) de Cidinha da Silva, publicado no livro Um exu em Nova York (2019), pela Editora Pallas. ${ }^{3}$

$O$ conto parece tratar de um mero encontro entre a narradora, que não tem nome, e um homem chamado Zebrinha Onirê. Cabe ressaltar que o personagem é uma referência a uma figura importante da cena cultural baiana, chamado José Carlos Arandiba, um dos maiores coreógrafos e bailarinos do Brasil. Esse personagem sobe rindo "a escada de três em três degraus" (SILVA, 2019, p. 19) e deparase com a narradora que, "com a devida deferência ao filho de um rei" (SiLva, 2019, p. 19), lhe pergunta: "como vai? Tudo bem?" e Zebrinha logo lhe responde: "Que mal vai com o povo de Ogum?" (Silva, 2019, p. 19). Como se tivesse percebido que algo está incomodando a narradora. Nos contos de Cidinha da Silva, é notável a recorrência a mitos e deuses das religiões de matriz africana. A pergunta de Zebrinha, então, não é apenas retórica, mas supõe uma referência meio implícita, como se houvesse aí também uma piscadela de olho para o leitor, um convite para que o leitor acrescente à tentativa de interpretação do texto a referência ao orixá e o que isso pode significar para a narrativa. A pergunta engendra um fluxo de pensamentos na narradora, que olha "através dele" (Silva, 2019, p. 19), como que distraída com a situação. A boa forma de Zebrinha contrasta com os problemas físicos que a narradora vinha enfrentando, como "as dores e nódulos do vasto lateral" (SILVA, 2019, p. 19), mas também, com várias outras preocupações, como "a personagem frouxa do conto que precisava acertar” (Silva, 2019, p. 19).

3 Essa análise já foi apresentada, de forma sucinta, no post intitulado "As escritoras mulheres 'de cor” (2020), publicado no blog Leituras Contemporâneas - Narrativas do Século XXI, pela pesquisadora de iniciação científica Samara Lima. Disponível em: https://leiturascontemporaneas. org/2020/03/12/a-autorrepresentacao-do-negro-e-o-retorno-do-recalcado/ 
Zebrinha Onirê logo exige uma resposta, que a narradora, "de volta à cena" (SILVA, 2019, p. 20), agora sim presente no diálogo, responde: "mal não há no caminho dos filhos de Ogum. Nem no meu, amiga dos filhos dele" (Silva, 2019, p. 20). $\mathrm{O}$ encontro com essa figura tão simbólica parece acionar um gatilho na narradora, que percebe que não está bem, está em desarmonia com sua mente, seu corpo e seu espírito. A personagem que no decorrer da história aparenta estar perdida, aos poucos se encontra. Ogum é o orixá que abre caminhos com a força de sua espada e é nesse momento que os princípios de cura da narradora se cruzam. Após o encontro, a personagem resolve fazer o "caminho das Ássanas e das agulhas" (SILVA, 2019, p. 20), ou seja, recorre à yoga e à acupuntura para tranquilizar a mente e tratar as dores que sente no joelho. Mas é como se a personagem só pudesse se sentir leve e decidida, após o encontro com Zebrinha Onirê.

E o que pode significar o título do conto? O primeiro metal pode sugerir, então, o saber ancestral africano, a força do encontro com o filho de Ogum, que é o orixá da guerra e senhor dos metais; o segundo metal do título refere-se à agulha da acupuntura, uma técnica tradicional da medicina chinesa. É a partir da imbricação desses dois saberes que a personagem pode encarar suas outras preocupações e tratar o joelho, que estava "enquizilado por inseguranças do pé durante a caminhada" (SILVA, 2019, p. 20).

É curioso como Cidinha da Silva não coloca em tensão a imagem da religião africana com a representação negativa do imaginário social, que insiste em associar essa religião a coisa ruim. Isso não quer dizer que a autora seja alienada. Ela sabe que existe racismo na sociedade e que por isso é fácil encontrar hostilidade às religiões de matriz africana. Mas optou por produzir outra maneira de pensar política e literariamente. A autora parte diretamente para a simbologia africana, causando um estranhamento e exortando o leitor à decodificação das referências utilizadas. Ao passo em que parece questionar o leitor: por que a estranheza em (re)conhecer essas outras subjetividades e conhecimentos, já que estão enraizados em nosso cotidiano e fazem parte da nossa história?

Lívia Natália, em seu texto Literatura adoxada: as formas de escrita poética da negritude na cosmogonia afro-brasileira (2019), discute sobre como a literatura produzida pelos sujeitos negros no Brasil tem, desde meados do século XX, utilizado as representações das religiões afro-brasileiras como forma de militância e combate ao racismo. Assim, esses autores, cada vez mais, buscam inserir divindades africanas em suas literaturas. Porém, essas representações ultrapassam a ideia de adereço fantástico. Essas entidades aparecem enquanto motores de reflexão e portadores de conhecimentos ancestrais. Como no conto de Cidinha da Silva, em que o princípio de cura só foi possível a partir do encontro com Ogum.

Podemos afirmar, portanto, que no caso da narrativa de Cidinha da Silva, a autorrepresentação parece ter superado o confronto do imaginário que a branquitude estabelece com a representação negra, pois ao lançar mão dos símbolos e construir uma poética baseada no universo religioso de matriz africana, assume 
uma escrita que também é crítica a partir da "posição quilombola de observação do mundo" (2016).

Muitas narrativas contemporâneas de autoria negra buscam reverter os estereótipos negativos direcionados à população negra ao invés de criar alternativas radicais para essas representações. Talvez ainda seja importante e necessário confrontar tais estereótipos e pôr em xeque, no campo literário, a representação negra no imaginário da branquitude. Uma vez que não é raro discursos acusatórios afirmarem que o "racismo não existe", ainda que $76 \%$ da população negra viva em situação de vulnerabilidade, sem acesso aos direitos básicos, como mostra o dado do Instituto Brasileiro de Geografia e Estatística (IBGE), em 2014. ${ }^{4}$

Seja encarando a dualidade das representações da negritude e da branquitude, seja afirmando-se positivamente com valores que constroem o empoderamento dos sujeitos negros a partir da evocação a um imaginário próprio da negritude, as narrativas aqui analisadas utilizam diferentes perspectivas para inscreverem um posicionamento sobre as maneiras de (auto) representação do negro na literatura atual, valorizando, assim, a pluralidade crítica na forma de combater a branquitude e conceber a negritude. Ou, para falar como Franz Fanon: "Não há um preto, há pretos".

\section{Referências}

Bloom, Harold. O cânone ocidental. Rio de Janeiro: Objetiva, 2010.

Deleuze, Giles; Guattari, Félix. Kafka: para uma literatura menor. Tradução de Cíntia Vieira da Silva. Belo Horizonte: Autêntica Editora, 2017.

Duarte, Eduardo Assis. Estratégias de caramujo. In: Machado de Assis afrodescendente. Duarte, Eduardo Assis (Org.), Rio de Janeiro: Pallas; Belo Horizonte: Crisálida, 2009.

DuArte, Eduardo Assis. O negro na literatura brasileira. Navegações, Lisboa, v. 6, n. 2, p. 146-154, 2014. Disponível em: https://revistaseletronicas.pucrs.br/ojs/index. $\mathrm{php} /$ navegacoes/article/view/1678. Acesso em: 2 julho 2020.

Emicida. 'A pior coisa é você perguntar as horas e a pessoa esconder a bolsa', diz Emicida sobre o racismo no Brasil. [Entrevista concedida à] Júlia Dias Carneiro e Renata Mendonça. BBC Brasil, São Paulo, 1 de setembro de 2015. Disponível em: https://www.bbc.com/portuguese/noticias/2015/o9/150824_entrevista_ emicida_jc_rm. Acesso em: 8 março 2021.

Evaristo, Conceição. Da representação à auto-representação da Mulher Negra na Literatura Brasileira. Revista Palmares. Brasília, ano 1, n. 1, p. 52-57, 2005. Dispo-

4 Ver matéria "Negros representam $54 \%$ da população do país, mas são só $17 \%$ dos mais ricos." Disponível em: https://economia.uol.com.br/noticias/redacao/2015/12/o4/negros-representam-54-dapopulacao-do-pais-mas-sao-so-17-dos-mais-ricos.htm. 
nível em: http://www.palmares.gov.br/sites/ooo/2/download/52\%20a\%2057.pdf. Acesso em: 13 julho 2020.

GonçAlves, Ana Maria. Literatura dos povos que faltam. Revista Revera. Instituto Vera Cruz, v. 4, p. 102-122, 2019. Disponível em: https://site.veracruz.edu.br/ instituto/revera/index.php/revera/article/view/95. Acesso em: 13 julho 2020.

Hall, Stuart. Cultura e Representação. Tradução: William Oliveira e Daniel Miranda. Rio de Janeiro: PUC- Rio: Apicuri, 2016.

Hooks, bell. Olhares negros: raça e representação. Tradução de Stephanie Borges. São Paulo: Elefante, 2019.

LimA, Samara. As escritoras mulheres de "cor". Leituras contemporâneas narrativas do século XXI, Salvador, 23 abril 2020. Disponível em: https:// leiturascontemporaneas.org/2020/04/23/as-escritoras-mulheres-de-cor/. Acesso em: 8 março 2020 .

Martins, Geovani. O sol na cabeça. São Paulo: Companhia das Letras, 2018.

Menezes Neto, Hélio Santos. "Exposições e críticos de arte afro-brasileira: um conceito em disputa". In: Histórias Afro-Atlânticas: antologia. 1 ed. São Paulo: MASP, 2018.

MussA, Alberto. Rascunho, Curitiba, 22 dezembro 2011. Disponível em: http:// rascunho.com.br/alberto-mussa/. Acesso em: 1 jun. 2020.

Proença Filho, Domício. A trajetória do negro e a literatura brasileira. Estudos Avançados. São Paulo. vol.18 n.5o, p. 161-193, 2004.

Rankine, Claudia. Eu queria saber os que os homens pensavam de seu privilégio. Então perguntei. Revista Serrote, v. 33, p. 76-94, nov, 2019.

Silva, Cidinha. Entrevista ao Portal Geledés, 2016. Disponível em https://www. geledes.org.br/narrativas-de-um-lugar-de-fala/. Acesso em: 2 julho 2020.

Silva, Cidinha. Um exu em Nova York. Rio de Janeiro: Editora Pallas, 2019.

Sobral, Cristiane. O tapete voador. Rio de Janeiro: Editora Malê, 2016.

Sobral, Cristiane Sobral. "Quem não se afirma não existe": Entrevista com Cristiane Sobral. Entrevista concedida a Graziele Frederico, Lúcia Tormin Mollo e Paula Queiroz Dutra. Brasília. Maio/Ago, 2017. Disponível em: https://www.scielo.br/ pdf/elbc/n51/2316-4018-elbc-51-00254.pdf. Acesso em: 26 julho 2020.

SouzA, Florentina. Autorrepresentação e intervenção cultural em textualidades afro-brasileiras. Revista da Associação Brasileira de Pesquisadores/as Negros/as $(A B P N)$, v. 1, p. 183-194, 2010. Disponível em: http://abpnrevista.org.br/revista/ index.php/revistaabpn1/article/view/2960. Acesso em: 27 julho 2020. 
SouzA, Lívia Maria Natália de. Literatura Adoxada: As formas de escrita poética da negritude na cosmogonia Afro-brasileira. fólio - Revista de Letras, UESB, v. 10, n. 2, p. 193- 204, 2019. Disponível em: http://periodicos2.uesb.br/index.php/folio/ article/view/456o. Acesso em: 27 julho 2020.

Recebido em 31 de julho de 2020.

Aprovado em 8 de abril de 2021.

\section{Resumo}

\section{A (auto)representação do negro no conto brasileiro contemporâneo}

\section{Luciene Azevedo e Samara Lima}

O ensaio tem como principal objetivo discutir a noção de autorrepresentação em produções da literatura brasileira recente. Tomando como fundamento teórico os estudos propostos por bell hooks em seu livro Olhares negros: raça e representação (2019) e as discussões empreendidas por Souza (2010), Rankine (2019), Gonçalves (2018), pretendemos discutir e analisar o posicionamento afirmativo cada vez mais recorrente na literatura brasileira por parte dos escritores afrodescendentes que buscam marcar um lugar de presença, por meio de diferentes recursos literários, para questionar os estereótipos que, por muito tempo, estiveram presentes no discurso literário brasileiro. Assim, pretende-se refletir sobre o elo entre o autor, sua etnia e seu projeto literário, caracterizando melhor diferentes estratégias de "autorrepresentação" do negro em três contos de autores negros da literatura contemporânea brasileira: "Metal-Metal" de Cidinha da Silva (2019), "Espiral" de Geovani Martins (2018) e "Elevador a serviço" de Cristiane Sobral (2016).

Palavras-chave: autorrepresentação, Cidinha da Silva, Geovani Martins, Cristiane Sobral, literatura contemporânea. 